\title{
PENDAMPINGAN USAHA GIPANG SINGKONG DALAM MENINGKATKAN PEMASARAN DI ERA PANDEMI COVID-19
}

Ratu Sifa Ni'mah ${ }^{1}$, Intan Permatasari ${ }^{2}$, Nurul Hikmah ${ }^{3}$, Puput Lestari ${ }^{4}$, Ajeng Afifah Muhartini ${ }^{5}$

(2,3,) Program Studi Manajemen, Fakultas Ekonomi dan Bisnis, (4) Program Studi Sistem Informasi, Fakultas Ilmu Komputer, (5) Program Studi Statistika, Fakultas Sains Dan Teknologi Universitas Bina Bangsa E-Mail: Ratu.sifa.uniba@gmaial.com ${ }^{1}$, kkmkramatlabanpadarincanguniba@gmail.com $^{2}$,

\section{Puputlestarii15@gmail.com ${ }^{4}, \underline{\text { Muhartiniajeng@gmail.com }}^{5}$}

\begin{abstract}
The purpose of the Student Work Lecture Community Service Program is to increase the village potential and marketing of Gipang Dangdeur (cassava) in Kramatlaban village. The making of gipang is the object of this dedication. By using SWOT analysis, several problems were found as a result of internal weaknesses and external threats. The method of implementing this service is by using the Participation Action Research (PAR) method where the implementation is carried out through a participatory approach method, the implemented into an action, survey through observation, interviews, and analysis of village problems and potentials. Limited production, traditional manufacturing process and competition from Gipang produced by other regions. With this activity, the MSME group has product labels and marketing strategies using social media such as Instagram, Shopee, Facebook, WhatsApp which are carried out through digital technology. Directly through digital technology, it is able to increase and develop the selling value of cassava gipang craftsmen so that products can increase during the Covid-19 period. Several suggestions and proposals were generated, eith the hope that after implementation they would increase the marketing and selling value of the Gipang products, thereby increasing the welfare of the makers in particular and the people of the entire Kramatlaban village in general.
\end{abstract}

Keywords: SWOT Analysis, PAR Analisis, Gipang, Kramatlaban, Vilage Potential, Community Service.

\begin{abstract}
Abstrak
Tujuan Program Pengabdian Masyarakat Kuliah Kerja Mahasiswa adalah untuk meningkatkan potensi desa dan pemasaran Gipang Dangdeur (singkong) di desa Kramatlaban. Pembuatan gipang adalah obyek dari pengabdian tersebut. Dengan menggunakan Analisa SWOT ditemukan beberapa permasalahan akibat dari kelemahan internal maupun ancaman dari luar. Metode pelaksanaan pengabdian ini yaitu dengan menggunakan metode Participation Action Research (PAR) dimana dalam pelaksanaannya dilakukan melalui metode pendekatan secara partisipatif, kemudian diimplementasikan ke dalam sebuah aksi, survey melalui pengamatan, wawancara, dan analisis permasalahan dan potensi desa, Permasalahan diantaranya di sisi pemasaran yang terbatas, proses pembuatan yang tradisional serta persaingan Gipang produksi daerah lain. Dengan adanya kegiatan ini kelompok UMKM mempunyai label produk dan Strategi peasaran dengan menggunakan media sosial seperti Instagram, Shopee, Facebook, WhatsApp yang dilakukan melalui teknologi digital. Secara langsung dengan melelui teknologi digital mampu meningkatkan dan mengembangkan nilai jual pengrajin UMKM gipang singkong sehinggga produk dapat meningkat di masa Covid-19. Beberapa saran dan usulan dihasilkan, dengan harapan setelah dilaksanakan akan meningkatkan pemasaran dan nilai jual dari produk Gipang tersebut, sehingga meningkatkan kesejahteraan para pembuat khususnya dan masyarakat seluruh desa Kramat Laban umumnya.
\end{abstract}

Kata Kunci: Analisa SWOT, Analisa PAR, Gipang, Kramatlaban, Potensi Desa, Pengabdian Masyarakat.

PENDAHULUAN 
Pandemi Covid-19 memberi dampak ketidakstabilan ekonomi, termasuk usaha mikro kecil menengah (UMKM). Secara umum, mayoritas dari pelaku UMKM mengalami penurunan pendapatan bahkan kebangkrutan akibat pandemic Covid-19. Menghadapi hal demikian diperlukan strategi bagi UMKM untuk tetap bertahan dan dapat mengembangkan bisnisnya di tengah masa pandemi Covid-19. Aspek utama yang sangat berdampak bagi pelaku UMKM salah satunya adalah penurunan jumlah penjualan yang membuat kondisi keuangan UMKM dalam kondisi krisis. Pembatasan kegiatan sosial atau PPKM membuat UMKM sangat sulit bergerak mengembangkan skala usaha jika hanya memanfaatkan metode konvesional tersebut (Sulistyo A.B. 2020).

Gipang singkong merupakan salah satu usaha mikro UMKM makanan khas Desa Kramat Laban Kecamatan Padarincang, yang mana sangat membutuhkan pendampingan dalam upaya meningkatkan prekonomian di daerah tersebut. Kurangnya mobilitas masa disekitar pasar tertentu menghambat laju promosi yang berpengaruh kepada tingkat penjualan. Mengatasi hal tersebut, pemasaran secara online melalui media merupakan langkah tepat yang harus dilakukan oleh para pelaku usaha. Salah satu langkah yang dapat dilakukan oleh pelaku UMKM adalah dengan meakukan optimalisasi digital marketing terutama dalam sektor peningkatan social media marketing (Observasi UMKM Gipang Singkong Kramatlaban. 2021)

\section{Desa Kramat Laban}

Desa Kramat Laban terletak di kecamatan Padarincang kabupaten Serang dan provinsi Banten dan memiliki luas $226 \mathrm{Ha}$. Desa ini berbatasan sebelah utara dengan desa Ranca Sanggal kecamatan Cinangka, sebelah selatan dengan desa Cibojong dan desa Kadubereum. Sedangkan batas di sebelah Barat adalah desa Tanjungmanis kec. Cinangka dan di sebelah Timur dengan desa Bugel kecamatan Padarincang. Total jumlah penduduk sekitar 5,000 jiwa dan mayoritas bekerja di sektor pertanian atau pekebunan, dimana menempati area seluas setengah dari luas desa, yaitu $103 \mathrm{Ha}$. Sementara untuk usaha di bidang yang lain adalah perikanan, peternakan dan kerajinan, walaupun jumlahnya masih minoritas, termasuk pembuat Gipang. Walau jumlah pembuat Gipang tidak banyak, tetapi hasil produk Gipang desa Kramat Laban cukup dikenal, karena punya keunikan tersendiri, dan berbeda dengan produk Gipang daerah lain (Profil Desa Kramatlaban. 2019). 


\section{Analisa SWOT}

Analisi SWOT adalah sebuah metode perencanaan yang digunakan untuk mengevaluasi kekuatan (Strength), Kelemahan (Weakness), peluang (Opportunity) dan ancaman (Threat) yang terjadi dalam proyek atau disebuah usaha bisnis atau mengevaluasi lini-lini produk sendiri maupun pesaing. (Rangkuty F. 2019).

\section{Analisa PAR}

Metode penelitian PAR adalah sebuah metode penelitian dan pengembangan secara partisipasi yang mengakui hubungan sosial dan realitas pengalaman, pikiran dan perasaan kita. Dengan adanya hubungan sosial yang terjalin antara tim pengabdian dan masyarakat Desa Kramat Laban sangat mendukung proses dalam pembuatan gipang dangdeur. (Bahri S \& Futiah V. 2020).

\section{Gipang Dangdeur Kramat Laban}

Gipang adalah makanan tradisional di Banten seperti gula-gula maupun teng-teng kacang dan jagung, meski jarang bisa lagi ditemui dengan mudah di pasaran, nyatanya sekarang Gipang punya banyak varian toping. Gipang sendiri punya banyak nama dan jenis. Ada yang menyebutnya Jipang, Gipang, Teng-teng, Ting-ting, ada juga yang berbentuk gulagula kacang dan jagung. Perbedaan tersebut biasanya karena bahan dasarnya. Gipang sendiri biasanya berbahan dasar beras ketan. Namun, di desa Kramat Laban Gipang tersebut berbahan dasar singkong. Rasa Gipang sangat khas. Manis, kriuk-kriuk, teksturnya agak keras dan lengket saat digigit.

Cara membuat gipang tidak bisa sekali jadi dalam waktu singkat. Bisa sampai dua hari waktu pengolahannya. Mulai dari memarut, menjemur, menggoreng singkong (cangkaruk) dan menyeduh gula untuk mengkaramelisasinya. Meskipun demikian, bahannya mudah didapat untuk gipang singkong. Bahannya hanya terdiri dari singkong, gula merah atau gula pasir, asem jawa dan cetakan nampan kayu. Dalam pengolahannya, bisa juga singkong dipadukan dengan kacang tanah. Sehingga rasanya jadi lebih gurih.

Bentuk gipang biasanya persegi, persegi panjang atau bisa bulat sesuai selera. Disusun menumpuk di dalam plastik atau toples dan lengket saat diambil karena gula menjadi lem perekat alami. Bagi Anda penyuka camilan tradisional yang rasanya manis, Gipang yang krenyes-krenyes manis, dijamin membuat Anda ketagihan (Sumber Suara Jakarta. 2015). 

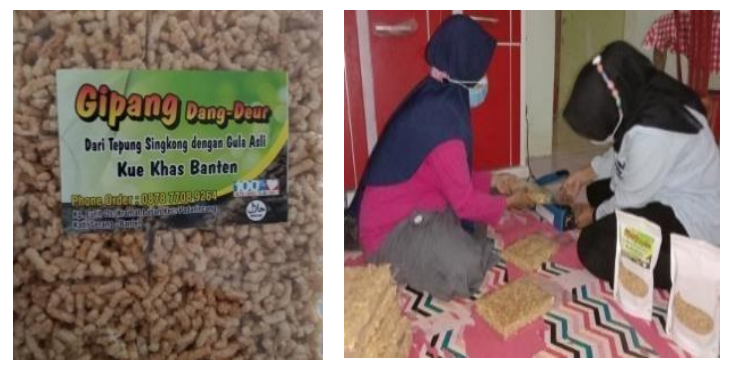

\section{Gambar 1. Contoh produk gipang dangdeur Kramatlaban}

\section{METODE PELAKSANAAN DAN BAHAN}

Kewirausahaan adalah tema yang kami pilih untuk KKM 2021, khususnya pembuat dan produksi Gipang di Kramat Laban. Dengan analisis SWOT, dimana mempertimbangkan potensi dan risk, beberapa langkah yang harus dilakukan untuk meningkatkan potensi dari produksi Gipang dan pemasarannya (Newton, P \& Bristoll, H. 2015). Berikut flow chart nya:

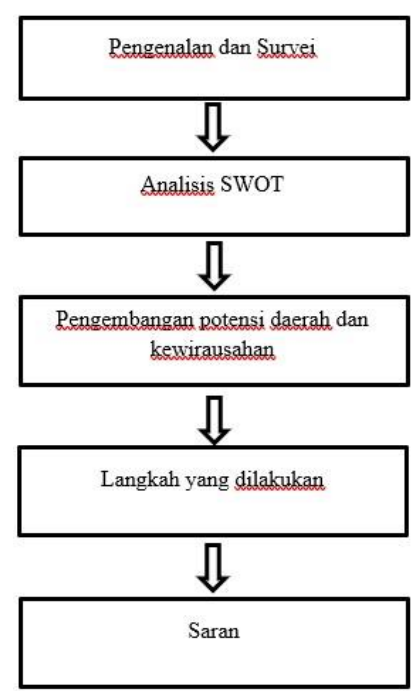

\section{Gambar 1.3 Flow chart jurnal Abdi Karya}

Langkah pengenalan dan survey adalah Pengenalan proses pembuatan Gipang dari pembuat kepada mahasiswa KKM, pengenalan proses pembuatan Gipang dilakukan oleh mahasiswa KKM, agar supaya mahasiswa KKM bisa mendalami cara, kesulitan, kondisi para pekerja dan waktu yang dibutuhkan saat pembuatan. Walaupun dibutuhkan skill dan proses pembuatan yang tidak mudah, tetapi target dari para mahasiswa lebih fokus pada ke 
pemasarannya. Sedangkan harga dari Gipang Kramat Laban bervariasi mulai dari Rp 10.000

- Rp 15.000 sesuai dengan ukuran isinya. Tahapan - Tahapan Pembuatan Gipang:

1. Proses Pembuatan Cangkaruk.

Pertama kupas singkong dari kulitnya. Selanjutya singkong yang sudah dikupas tadi diparut dan dibuat menjadi opak atau kerupuk. Lalu digunting halus seperti butiran beras kemudian dijemur sehingga menjadi cangkaruk.

2. Cangkaruk yang sudah jadi kemudian digoreng.

3. langkah selanjutnya merebus gula bersama air dan asam jawa hingga menjadi caramel.

4. Setelah itu tuang diatas singkong atau cangkaruk yang sudah digoreng.

Campur hingga rata kemudian dicetak dalam cetakan gipang yaitu menggunakan nampan kayu, kemudian digiling hingga padat menggunakan botol gelas.

5. Setelah teksturnya padat, kemudian dipotong sesuai kemasan.

\section{HASIL DAN PEMBAHASAN}

\section{METODE SWOT}

Analisa SWOT terhadap Gipang

Dangdeur Kramat Laban Strenghts:

- Bahan baku yang mudah di dapat dan berkualitas.

- wilayah pembuatan Gipang (Desa Kramat Laban) yang memiliki, suhu, cuaca dan iklim yang cocok untuk proses penjemuran

Cangkaruk.

- Penyaluran distribusi mudah.

\section{Opportunities:}

- Gipang secara umum disukai banyak kalangan dan marketnya luas.

- Kebiasaan para konsumen yang mencari cemilan yang bergizi, murah dan rasa yang lezat.

- Gipang dapat dinikmati sebagai cemilan maupun oleh-oleh.

- Gipang Kramatlaban mendapatkan support penuh dari pemerintahan Desa Kramatlaban dan menjadi ciri khas dari desa tersebut.

- Gipang dangdeur Kramatlaban bias dikenal diluar daerah karena masih mempertahankan keunikan rasa Gipang yang diproduksi dari ampas singkong. Bentuk dan varian topingnya bisa disesuaikan dengan permintaan customer. 


\section{Weakness:}

- Kurangnya pemasaran.

- Keterbatasan waktu dan sumber daya manusia

- Kurangnya pengelolaan manajemen.

- Tradisional, proses pembuatan

Gipang Dangdeur masih menggunakan cara yang tradisional.

- Pembuat Gipang hanya berjumlah 1 orang yang membuat Gipang yang bisa di produksi tidak banyak dan proses pembuatannya membutuhkan waktu yang cukup lama (Pembuatan Cangkaruk).

\section{Threats:}

- Gipang dari desa lain lebih terkenal dibandingkan Gipang dari Desa Kramatlaban karena memiliki pangsa pasar yang luas.

- Pemasaran Gipang kramatlaban masih kurang efektif karena pembuat hanya menerima pesanan dari pelanggan yang biasa datang ke tempat produksinya.

Distribusi dari Gipang kramatlaban sendiri hanya ditawarkan kepada orang - orang terdekat seperti untuk oleh-oleh dan hari lebaran saja.

Dari Analisa SWOT diatas, demi meningkatkan potensi daerah dan mengembangkan para pembuat Gipang di desa Kramat Laban, langkah-langkah yang harus dilakukan oleh para pembuat dan pemerintah serta instansi terkait adalah sebagai berikut:

1) Meningkatkan pemasaran baik secara pasif maupun aktif

a) Secara Aktif

- Memasarkan Gipang melalui media online (Whatsapp, Facebook, Instagram)

b) Secara Pasif

- Menerima masukan dari customer untuk memperbaiki bentuk Gipang yang kurang baik

- Produksi Gipang dilakukan saat ada pesanan dari customer.

2) Mengenalkan produk Gipang disetiap pameran.

- Mahasiswa KKM 22 Kramat Laban membantu merealisasikan langkahlangkah diatas, seperti pembuatan akun dan lapak di online store. 


\section{METODE PAR}

Metode penelitian PAR adalah sebuah metode penelitian dan pengembangan secara partisipasi yang mengakui hubungan sosial dan realitas pengalaman, pikiran dan perasaan kita. Dengan adanya hubungan sosial yang terjalin antara tim pengabdian dan masyarakat Desa Kramat Laban sangat mendukung proses dalam pembuatan gipang dangdeur. Pendekatan dilakukan dengan observasi dan wawancara terkait kondisi usaha kelompok pembuatan gipang dangdeur, proses pembuatan produk hingga permasalahanpermasalahan dalam mengembangkan usaha pembuatan gipang dangdeur dimasa pandemic COVID'19 (Bahri S \& Futiah V. 2020).

Dalam hal ini, dapat diketahui cara pembuatan gipang yang berasal dari singkong atau dangdeur. Adapun tahapan tahapan dalam membuat gipang dangdeur yaitu:

Pertama, proses pembuatan produk diawali dengan membuat cangkaruk. Yaitu dengan mengupas singkong dari kulitnya. Lalu singkong yang dikupas tadi diparut dan dibuat menjadi opak atau kerupuk. Lalu digunting halus seperti butiran beras kemudian dijemur sehingga menjadi cangkaruk.

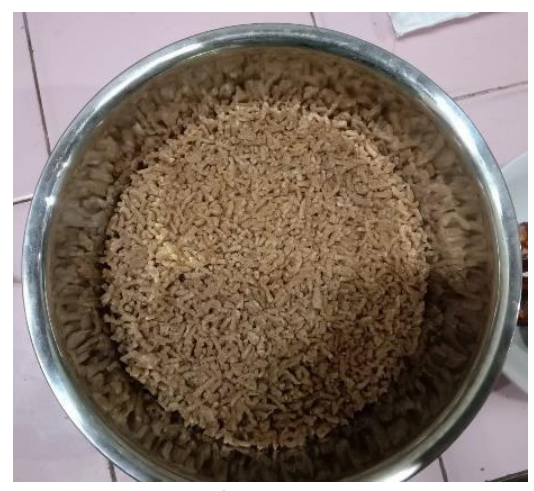

Gambar 1. Cangkaruk kering. 
Kedua, cangkaruk yang sudah kering kemudian di goreng.

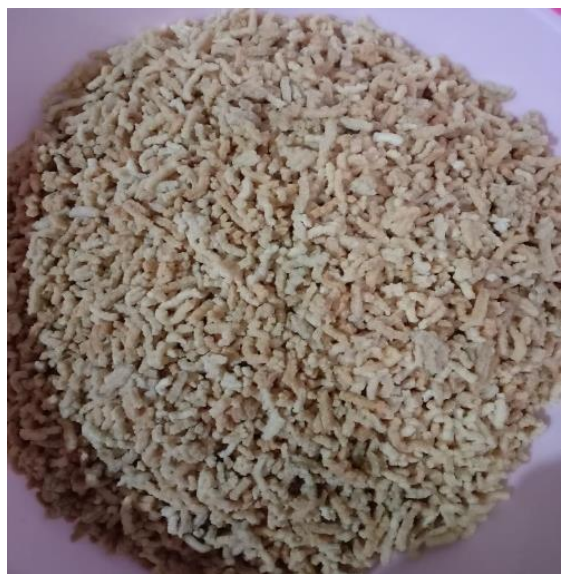

Gambar 2. Cangkaruk goreng.

Ketiga, merebus gula bersama air dan asam jawa hingga menjadi caramel.

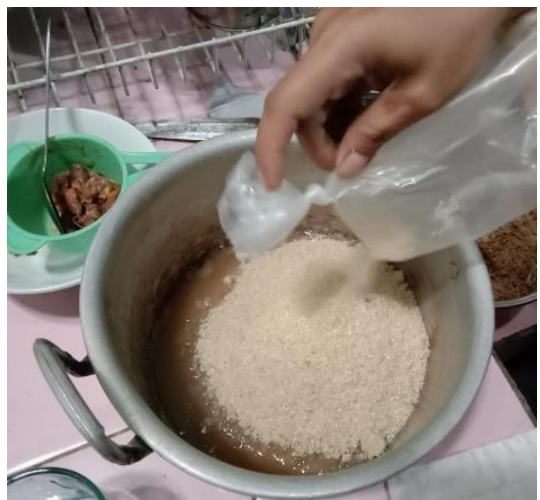

Gambar 3. Merebus gula dan asam jawa.

Keempat, cangkaruk yang sudah digoreng dicampur dengan caramel, lalu diaduk hingga rata.

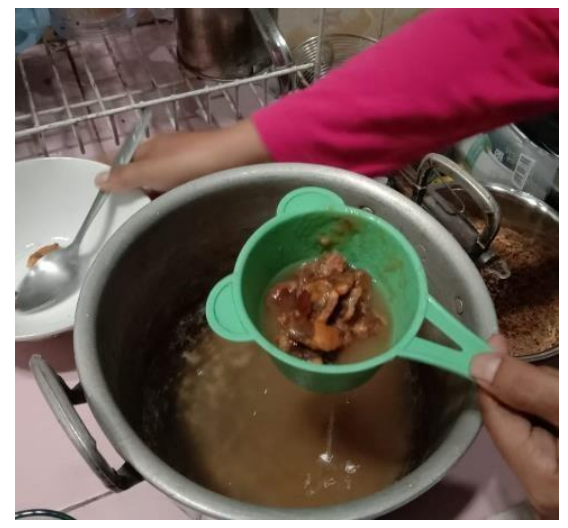

Gambar 4. Karamel 
Kelima, hasil dari campuran cangkaruk dan caramel dicetak dalam cetakan gipang yaitu menggunakan nampan kayu, kemudian digiling hingga padat menggunakan botol gelas.

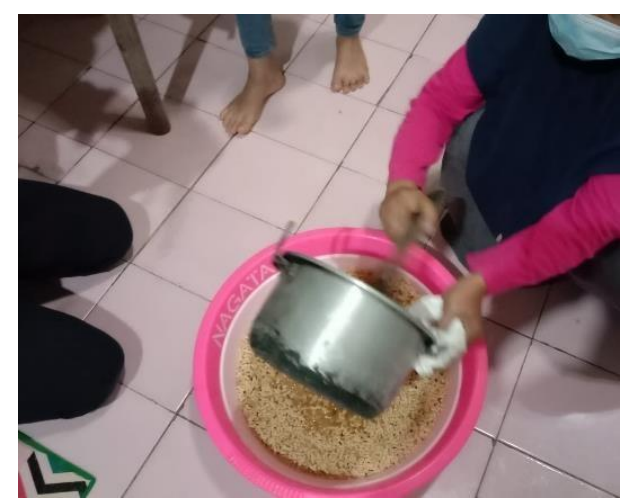

Gambar 5. Menyatukan cangkaruk dan caramel.

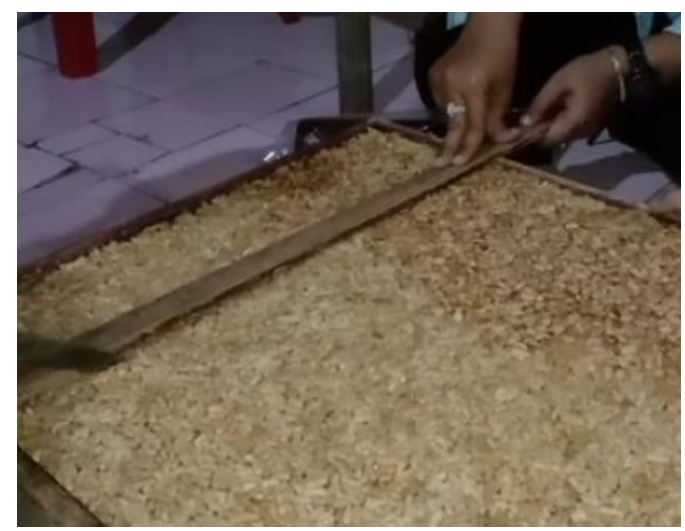

Gambar 6. Mencetak campuran cangkaruk dan caramel dalam cetakan gipang. Setelah teksturnya padat, kemudian dipotong sesuai kemasan.

Tahapan pemberdayaan selanjutnya pada metode PAR yaitu mengimplementasikan hasil pendekatan secara tepat. Yaitu dengan diberikan bekal berupa pengetahuan bagaimana mensiasati model marketing dimasa pandemic COVID'19 dengan menggunakan teknologi informasi yaitu melalui sosial media. Penggunaan sosial media bukan hanya mampu mengenalkan produk UMKM secara luas, tapi juga memberikan peluang yang sangat besar bagi pelaku UMKM desa Kramat Laban. 


\section{KESIMPULAN}

Setelah dilakukan kegiatan Kuliah Kerja Mahasiswa - Tematik berbasis Problem Solving untuk memecahkan masalah dengan tema "Kewirausahaan dan Pengembangan makanan khas Banten". Program kerja peningkatan potensi dan pemasaran Gipang di Kramat Laban belum maksimal, akan tetapi dilakukan secara bertahap. Follow up yang berkeseinambungan dan selalu melihat hasil dari setiap aktivitas yang dilakukan, selanjutnya dilakukan evaluasi, kami yakin tujuan bisa tercapai. Bila pengenalan produk semakin meluas, dengan meningkatkan strategi pemasaran, akan membuat Gipang Dangdeur Kramat Laban yang mempunyai keunikan tersendiri menjadi semakin dikenal. Dengan memberikan bekal berupa penggunaan sosial media yang bukan hanya mampu mengenalkan produk UMKM secara luas, tapi juga memberikan peluang yang sangat besar bagi pelaku UMKM desa Kramat Laban. Dengan semakin dikenalnya Gipang Kramat Laban, dan proses pembelian yang mudah dan gampang diakses, akan berakibat peningkatan penjualan dan produksi, sehingga kehidupan dan kesejahteraan para pembuat Gipang khususnya dan masyaratkat desa Kramat Laban pada umumnya semakin meningkat. Insya Allah.

\section{DAFTAR PUSTAKA}

Sulistyo A.B. 2020. Peningkatan Potensi Daerah Dan Pemasaran Golok

$$
\text { Di Desa Kramatlaban }
$$

Kecamatan Padarincang. Jurnal ilmiah. Vol. 2, No. 1.

Newton, P \& Bristoll, H. (2015). "SWOT

Analysis Strategy Skill" >http://www.freemanagementeb ooks.com/dldebkpdf/fmeswotanalysis.pdf< diakses pada 17 Agustus 2021.

Sumber Suara Jakarta, "Gipang Singkong, Camilan Khas Banten yang

Manis Krenyes", 16 Mei

2015> https://indonesiapunyaber itaku.blogspot.com/<(diakses pada 16 Agustus 2021)

Bahri S \& Futiah V. 2020. Pendampingan dan Pengembangan

Manajemen Pemasaran Produk UMKM Melalui Teknologi Digital Dimasa Pandemi Covid-19. Jurnal Loyalitas Sosial. Vol 2 (2). Hal 50-70.

LP2M. 2019. Diktat KKN PAR 2019. Lamongan: Institute Agama Islam

Tarbiyatut Tholabah Lamongan. 